\title{
Presence of Cavities in Snags Retained in Forest Cutblocks: Do Management Policies Promote Species Retention?
}

\author{
Kim T. EvERETT ${ }^{1,3}$ AND Ken A. OTter ${ }^{2}$ \\ ${ }^{1}$ Forestry Program, University of Northern British Columbia, Prince George, British Columbia V2N 4Z9 Canada \\ ${ }^{2}$ Ecosystem Science \& Management Program, University of Northern British Columbia, Prince George, British Columbia \\ V2N 4Z9 Canada \\ ${ }^{3}$ Current Address: Department of Biology, University of Victoria, Victoria, British Columbia V8W 2Y2 Canada
}

Everett, Kim T., and Ken A. Otter. 2004. Presence of cavities in snags retained in forest cutblocks: do management policies promote species retention? Canadian Field-Naturalist 118(3): 354-359.

Tree cavities, which are frequently excavated by primary cavity nesters, are typically used by a number of avian and non-avian species and are thus important components in maintaining biodiversity in forest ecosystems. One way to provide these habitat opportunities in harvested areas is through the retention of snags. In this study, we assessed the habitat and snag characteristics that promote cavity excavation, using the presence of cavities to infer activity of primary cavity excavators. Snags retained closer to the forest/cutblock edge contained a greater density of cavities than trees further from edge. However, the proportion of cavities found within cutblocks declined at a more rapid rate with distance from edge than did those in adjacent forested stands. There was also a tendency for cavities to occur more frequently in trees that were at the advanced stages of decay. The results of our study suggest management for snags in harvest areas should include the retention of snags closer to the forest edge combined with incorporating trees showing signs of advanced decay.

Key Words: tree cavities, snags, forest edge, birds, mammals, reptiles, British Columbia.

Snags (standing dead trees) provide specialized habitat for many species, which in turn play an integral role in maintaining ecosystem functions (Machmer and Steeger $1995^{*}$ ). Approximately $16 \%$ of the indigenous birds, mammals, and reptiles in British Columbia depend to some extent on snags or cavities for reproduction, feeding, and shelter (Backhouse and Lousier $\left.1991^{*}\right)$. These dependent species then create habitat opportunities for other wildlife species, facilitate seed dispersal, increase soil aeration, accelerate organic decomposition, and can even aid in controlling forest pests (Machmer and Steeger 1995*). Although snags play an important role in the ecosystem, their removal has traditionally occurred in past forest management (ostensibly to reduce hazards - lightning attraction, falling snags, etc. - and foci of infection for healthy trees).

By retaining trees of varying ages, diameters, and decay classes in cutblocks, the vertical structure of vegetation, total percent vegetation, and percent deciduous cover increase. These changes can lead to greater species richness and diversity in both plant and mammal communities (Davis et al. 1999*). Population densities of cavity-nesting species are often limited by potential nest sites (Runde and Capen 1987), and intensive forest management that removes snags reduces their densities in managed stands compared to natural stands (Haapanen 1965; Pojar 1995).

Primary cavity nesters (those which excavate their own cavities, such as woodpeckers and some chickadees: Thomas et al. 1979) appear to prefer stands with a high number of snags (Zarnowitz and Manuwal 1985;
Raphael and White 1984). As most primary cavitynesting birds rarely occupy nests that they themselves have not excavated (Short 1979), suitable trees, including snags, must be available for excavation for nests or roosts. Snags offer softer excavating substrates as well as important foraging sites for these species. Conversion of natural forests into intensively managed stands which lack snags may, therefore, have long-term negative effects on the entire cavity-nesting populations, as secondary cavity-nesting species rely on primary excavators for cavity creation (Peterson and Grubb 1983).

Bodies that govern forestry practices recognize the importance of snags, and advocate the retention of a variety of tree species at various stages of decay in managed forests (e.g., Machmer and Steeger 1995*). In an effort to reduce the impact of large openings created by cutblocks, some forest companies retain windfirm deciduous trees and advanced regeneration that fall below utilization standards to aid in maintaining structural diversity in cutblocks. This limits the distance wildlife must travel through the cutblock without vegetative cover. The traditional paradigm has been that efforts such as these will be sufficient to maintain wildlife and biodiversity throughout managed forests.

One aspect of snag retention policy that has been overlooked, however, is the behavioral characteristics of primary cavity-nesting species that may deter members of this guild from occupying trees left specifically for their use. Many forest birds avoid areas outside forested cover (Hegner 1985; Desrochers and Hannon 
1997), as open spaces leave these species susceptible to hawk and falcon predation (Corral 1989). Several studies have shown that many forest dwelling species are reluctant to cross gaps between fragmented forested areas (Lens and Dhondt 1994; Desrochers and Hannon 1997). Desrochers and Hannon (1997) found that forest birds were three times less likely to cross gaps 70 metres wide, and eight times less likely to cross gaps 100 metres wide compared to similar distances within the forest. Machtans et al. (1996) also found that movement rates of forest birds across cutblocks were significantly lower than movement rates within the forest. Instead, forest birds preferred to travel much greater distances through corridors, rather than crossing narrow gaps (Desrochers and Hannon 1997).

The avoidance of open spaces indicated that forest birds - with the majority of those studied belonging to the cavity-nesting guild - have fewer habitat opportunities as the landscape becomes increasingly fragmented. Although retained snags may be scattered throughout cutblocks to provide nest sites, the gap between the forest edge and the snag may be too substantial for birds to cross. In turn, the number of cavitynesting birds may decline with increased distance into cutblocks as compared to the surrounding forest.

In this study, we documented the presence of cavities in retained snags within forest cutblocks as a measure of use by cavity-excavating species, and compared this to similar trees found within the surrounding forest. If primary cavity nesting species avoid openings in forest cover, we predict fewer cavities as one travels further from the forest edge into cutblocks. By assessing attributes of cavity-possessing trees, we attempt to identify which tree characteristics and tree species cavity nesting birds tend to utilize. Our aim is to provide well-substantiated recommendations towards the placement and creation of retained snags within cutblocks that maximize potential usage by cavity nesting species.

\section{Methods}

\section{Study Area}

This study was carried out from 30 September to 5 November 2000, approximately 30 kilometers west of Prince George, British Columbia (53036'35"N, $122^{\circ} 57^{\prime} 29^{\prime \prime}$ ). All samples were located within the Sub-Boreal Spruce biogeoclimatic zone, which covers much of the central interior of British Columbia (MacKinnon et al. 1992). The study area was primarily composed of coniferous and mixedwood forests, with species including Lodgepole Pine (Pinus contorta var. latifolia), hybrid White Spruce (Picea glauca $\times$ engelmannii), Sub-alpine Fir (Abies lasiocarpa), Douglas-fir (Pseudotsuga menziesii var. glauca), Trembling Aspen (Populus tremuloides), Black Cottonwood (Populus balsamifera ssp. trichocarpa) and Paper Birch (Betula papyrifera). Harvested areas are typically replanted with Lodgepole Pine, with a small component of hybrid White Spruce on moister sites.

\section{Sampling Procedure}

We randomly selected eight cutblocks for the survey from a Forest Development Map. The cutblocks ranged in age from 3 to 10 years post-harvest, and from 30 to 60 hectares in size. A line-transect method of sampling was used. In this method, all retained snags falling within 5 metres of each side of the transect were measured. We ran transects on a bearing perpendicular to the forest edge, with a random point of commencement along the edge being selected from the Forest Development map. Measurements were carried out until the centreline of the cutblock was reached and at least 20 snags were encountered. In one case, the cutblock contained only 17 retained snags. Due to the minimal number of retention trees present, the line-transect method would have been relatively ineffective; therefore; all retention trees in the cutblock were measured.

Snags were defined as any dead, standing tree (Smith et al. 1997: 489). We recorded all cavities that were either actively excavated or were natural cavities of similar size, which displayed signs of active use (e.g., modification to the cavity, presence of feathers in entrance, etc.). Cavities were only recorded if they had a minimum diameter of $3.5 \mathrm{~cm}$, as the cavity had to be large enough for use by a small bird or mammal. However, as our study was looking for evidence of use of the trees rather than specifically focusing on nesting, we did not distinguish between cavities used for roosting versus those where nesting had occurred. For each snag encountered along the transect, we recorded several attributes: tree species, height, diameter at breast height (DBH, measured at $1.3 \mathrm{~m}$ from the base of the tree), decay class, number of cavities, distance from the nearest timber edge, percent overhead cover, and the number of snags and live trees within an $11.28 \mathrm{~m}$ radius around the trees. Only trees greater than 10 centimeters DBH were recorded, as this reduced the chance of incorporating regeneration into the study. Decay class was determined using a six-step hardwood classification scheme combined with a corresponding ninestep coniferous classification scheme (Ministry of Forests 2000*).

Similar transects were placed in the adjacent forested stands running perpendicular to the edge. In order to measure a similar number of trees over the same distance in both habitat types, every third tree classified as decay class 2 or greater was measured. In order to determine the initial tree for measurement along each transect, a coin toss was completed to decide if the first or second tree should be measured. For each tree encountered along transects in forested stands, the same attributes were measured as those collected for cutblock sampling.

\section{Statistical Analysis}

A multiple regression was used to determine if the habitat (forest or cutblock) and distance from the forest edge influenced the proportion of cavities found (SYSTAT 9.01). To compare the distribution of tree 
types across the two habitats, we employed a Chisquare and used a Mann-Whitney $U$ test to compare the frequency of decay classes of trees between cutblocks and forested stands.

To determine which characteristics tended to predict the presence of cavities in wildlife trees, we conducted a Principal Component Analysis (PCA) on trees in the forested stands. As the forest stands constitute the natural habitat of many of the primary cavity-nesting species, determining the characteristics of cavity-bearing trees in these areas may give insight into which types of wildlife trees are important to retain in cutblocks. The following characteristics of the focal tree and the immediate area were subjected to PCA: height, diameter, and decay class of the focal tree, along with the total number of trees, number of live trees, number of snags, and percent overhead cover within the 11.28 metre radius plot. A linear regression was used to compare the number of tree cavities against the PCA factor scores. The PCA was carried out in SYSTAT 9.01 using Varimax rotation.

Two retention trees measured had extremely high numbers of cavities and were identified during initial analysis as significant outliers in the data set (DurbinWatson D Statistic $=1.984, P<0.01)$. These were excluded from subsequent analysis.

\section{Results}

In total, 185 trees were measured at our eight sampling sites; 94 trees within cutblocks and 91 trees within forested stands. We found 46 cavity-bearing trees, containing a total of 67 cavities. Of the 46 trees containing cavities, 29 were deciduous while the remaining 17 were conifers.

A greater proportion of deciduous trees contained cavities compared to coniferous species. Species of willow had the highest proportion of cavities, with two of the three trees observed containing cavities.
Trembling aspen was found to have the second highest frequency of cavities with 17 of the 62 trees observed containing cavities. A breakdown of the number of cavities recorded by species is given in Table 1 .

The species composition of trees differed between the two habitats $\left(\chi^{2}=76.6, \mathrm{df}=6, \mathrm{p}<0.01\right.$ - Figure 1$)$. Snags in cutblocks were primarily deciduous species; although these trees were also present in forested stands, the latter stands had a proportionately higher coniferous component.

\section{Distance From Edge and Cavity Abundance}

Distance from forest edge and stand type (cutblock or forest) both had a significant effect on the number of cavities found (multiple regression: $\mathrm{r}^{2}=0.051$, $\left.\mathrm{F}_{(2,180)}=4.857, \mathrm{p}=0.009\right)$. The further a tree was located from the forest-cutblock edge, the lower the frequency of cavities $(p=0.027)$. There was also a significant effect between the stand types, as more cavities were found in the forest than were found in the cutblock $(p=0.020)$. In the forest stands, the decline in number of cavities found with distance from the edge was not as dramatic as that seen in cutblocks (Figure $2 \mathrm{a}$ and $\mathrm{b})$.

\section{Stand Characteristics Associated with Snags}

The principal component analysis identified two factors that accounted for $56.2 \%$ of the total variance among retained snags (Table 2). Principal component one (PC 1) accounted for $31.2 \%$ of the variance, with strong positive weightings for a high number of total trees and a high number of live trees within an $11.3 \mathrm{~m}$ radius plot. As a result, PC 1 can be considered a measure of the density of trees surrounding the snag.

Principal component two (PC 2) accounted for $25.0 \%$ of the total variance, with a strong positive weighting for decay class and a strong negative weighting for tree height. PC 2 indicates trees at the latter stages of the decay process, as tree height frequently decreases

TABLE 1. A breakdown of the number of cavities by tree species.

\begin{tabular}{|c|c|c|c|c|}
\hline Tree Species & $\begin{array}{c}\text { Number } \\
\text { of trees } \\
\text { observed }\end{array}$ & $\begin{array}{c}\text { Total number } \\
\text { of trees } \\
\text { with cavities }\end{array}$ & $\begin{array}{c}\text { Percentage } \\
\text { of trees } \\
\text { with cavities }\end{array}$ & $\begin{array}{c}\text { Total number } \\
\text { of cavities }\end{array}$ \\
\hline \multicolumn{5}{|l|}{ Trembling Aspen } \\
\hline Populus tremuloides & 62 & 17 & 27.4 & 32 \\
\hline \multicolumn{5}{|l|}{ Lodgepole Pine } \\
\hline Pinus contorta var. latifolia & 52 & 13 & 25.0 & 14 \\
\hline \multicolumn{5}{|l|}{ Paper Birch } \\
\hline Betula papyrifera & 32 & 8 & 25.0 & 10 \\
\hline \multicolumn{5}{|l|}{ Hybrid Spruce } \\
\hline Picea glauca $\times$ engelmannii & 24 & 4 & 16.7 & 5 \\
\hline \multicolumn{5}{|l|}{ Willow } \\
\hline Salix sp. & 3 & 2 & 66.7 & 3 \\
\hline \multicolumn{5}{|l|}{ Black Cottonwood } \\
\hline Populus balsamifera ssp. trichocarpa & 8 & 2 & 25.0 & 3 \\
\hline \multicolumn{5}{|l|}{ Douglas Fir } \\
\hline Pseudotsuga menziesii glauca & 4 & 0 & 0 & 0 \\
\hline Total (Average) & 185 & 46 & $(24.9)$ & 67 \\
\hline
\end{tabular}




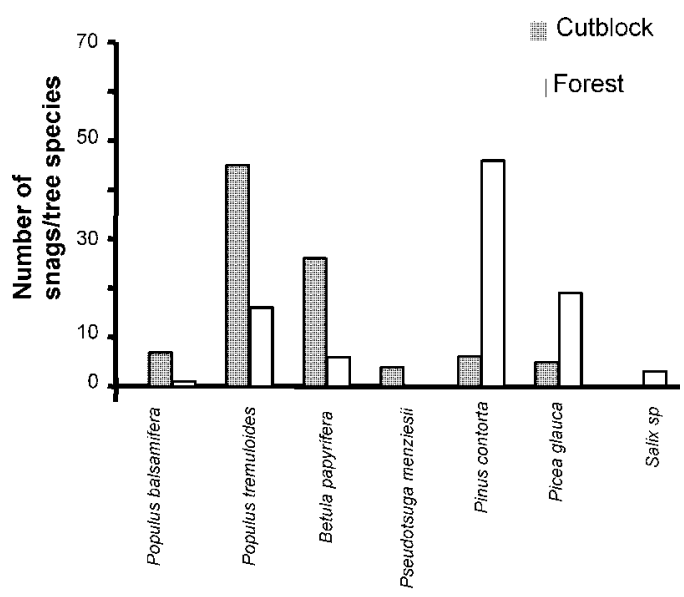

Tree Species

FIGURE 1. Distribution of sampled snags within cutblocks versus surrounding forest stands.

as the tree reaches the higher decay classes (Towers et al. 1992).

\section{Response of Cavity Nesters to Stand Characteristics}

There was no significant relationship between the number of cavities found and PC 1 (regression: $\mathrm{r}^{2}=$ $\left.0.003, \mathrm{~F}_{(1,90)}=0.281, \mathrm{p}=0.60\right)$. There was, however, a significant effect between the number of cavities being found and PC 2 (regression: $\mathrm{r}^{2}=0.092, \mathrm{~F}_{(1,90)}=9.13$, $\mathrm{p}=0.003$ ) indicating that more cavities occurred in trees with a higher amount of decay.

On average, the snags retained in clearcuts had less decay than the comparison cohort of trees in the forested areas (MWU: $\mathrm{U}=2918.5, \mathrm{n}=93,91, \mathrm{p}<0.01$ ).

Table 2. Principal component analysis of stand characteristics in forest stands. The first two Principal Components account for greater than $50 \%$ of the total variance among stand attributes; therefore only these two factors were considered in subsequent analysis. Variables that were within $10 \%$ of the highest loading were considered to be strong weightings, and are shown in bold.

\begin{tabular}{lcc}
\hline \hline Variable & $\begin{array}{c}\text { PC 1 } \\
\text { (clustering of } \\
\text { retention trees) }\end{array}$ & $\begin{array}{c}\text { PC 2 } \\
\text { (decay } \\
\text { stage) }\end{array}$ \\
\hline Tree Diameter & -0.407 & -0.395 \\
Tree Height & 0.272 & $\mathbf{- 0 . 7 1 4}$ \\
Decay Class & -0.353 & $\mathbf{0 . 7 3 8}$ \\
Total Number of Trees & $\mathbf{0 . 9 4 7}$ & 0.212 \\
Number of Live Trees & $\mathbf{0 . 9 5 6}$ & 0.115 \\
Number of Snags & 0.000 & 0.392 \\
Percent Overhead Cover & -0.029 & 0.573 \\
Percent of Total Variance & & \\
explained by each Factor & 31.15 & 25.02 \\
\hline \hline
\end{tabular}

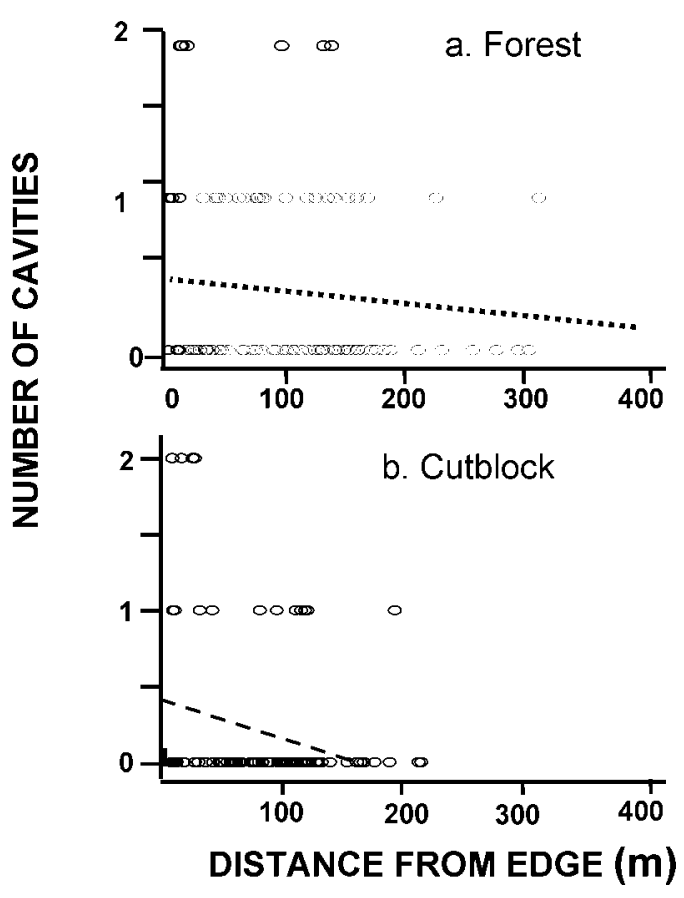

FIGURE 2. Regressions of distance from forest edge against the number of cavities located in trees in forested stands ( $\mathrm{a}$ - shown by a dotted line) and cutblocks ( $\mathrm{b}$ - shown by dashed line).

\section{Discussion}

\section{Edge Effects on Cavity-nesting Birds}

The number of cavities located within both cutblocks and forested stands were related to the distance from forest edge. Trees located farther from the forest edge had a tendency to contain fewer cavities than trees located closer to the forest edge. There was also a greater abundance of cavities located within forested stands than within cutblocks. Yet, although the number of cavities declined rapidly as the distance from cutblock edge increased, the equivalent decline was less rapid in forested stands. This suggests that retained snags farther from forest cover were underutilized by cavity-excavating species.

One possible bias in our results might arise if cavities found in the cutblocks existed prior to harvesting. Although we focused on measuring cavities that appeared to be recently used/excavated, it was occasionally difficult to distinguish between recently excavated cavities and cavities that may have existed prior to logging. However, if some of the cavities existed prior to harvest our results would over-estimate the level of activity of cavity-excavating species in cutblocks, thus minimizing the perceived effect of harvesting on cavity nesters. Despite the possible bias of including pre-existing cavities, we continued to see a reduced number of 
cavities in clearcuts. Thus, the magnitude of the effect we report may be even more pronounced between the different habitats.

Several possible explanations may exist for the lower densities of cavities within cutblocks. The reduced number of cavities in cutblock trees could be due to the reluctance of many species of forest birds to cross large openings. Desrochers and Hannon (1997) found that forest birds were extremely vulnerable to raptors when they fly in the open, and thus were hesitant to enter such areas. Secondly, the lower densities of tree cavities within cutblocks could be due to the retention of trees with minimal habitat value for cavity nesting species. Cavity nesters tended to prefer deciduous tree species, as a greater number of cavities were found in these trees than in coniferous tree species. In coniferdominated ecosystems, such as boreal and sub-boreal forests, deciduous trees often have greater heartwood decay than conifers and may be preferred as nesting substrate once the trees become snags, resulting in increased avian diversity (Martin and Eadie 1999). Yet, deciduous species accounted for a larger number of snags in the cutblocks than the forests in our study, and there was still a lower number of cavities in cutblocks than neighboring forests. While the retention of these deciduous snags likely increases diversity along the edge, the reluctance of birds to venture into cutblocks may have a larger influence on snag use farther from forest cover.

The highest density of cavities was located within 100 metres of the forest edge. Higher bird populations located at the forest edge compared to the community interiors has also been found in several other studies (see Gates and Gysel 1978; McElveen 1979; and Streikle and Dickson 1980). Several theories exist to support such behaviour. Marcot (1983) suggested that many cavity-nesting species nest in the nearby forest, whereas they use cutblocks for foraging, resulting in higher densities of birds seen along the community edge. Both the Northern Flicker (Colaptes auratus) and the Downy Woodpecker (Picoides pubescens), primary cavity excavators, prefer to nest in old trees near openings or on the edge of the forest (Ehrlich et al. 1988). Our results suggest this pattern may occur within our study area. Cavity density was highest at edges, but remained high for greater distances into forests than into cutblocks. Thus, marginal species attracted to edges may prefer to either nest on the edge or penetrate into the forest, rather than establish nests in snags retained in the cutblocks. Coupled with non-edge species, this would create the pattern of greater cavity abundance in forested sites.

\section{Tree Attributes and Cavity Abundance}

Within forested stands, cavities were found more often in trees that contained a combination of high levels of decay and shorter tree height. Decayed portions of the tree allow for easier cavity excavation for weaker cavity excavators, and the bark cover retains mois- ture and warmth as well as providing protection from predators (Runde and Capen 1987). Decayed portions of the tree also provide valuable foraging habitat as they often contain high levels of beetle larvae, carpenter ants, and termite activity, all of which act as food resources for woodpeckers (Mannan et al. 1980). This too may explain the lower use of cavities in cutblocks, as trees retained in these areas had less decay compared to trees sampled randomly in the surrounding forests. This is likely the result of trees with greater decay being removed as potential hazards during forestry operations. Retention of these higher decay class trees, however, may be valuable in future planning. It is important to retain trees at a variety of levels of decay, as the nesting success of some primary cavity excavators is higher in snags in the 2-3 decay class range (Fort and Otter 2004).

\section{Management Implications and Recommendations}

Primary cavity nesters require specific habitat conditions (Conner et al. 1976), and without these conditions territory selection and reproductive success may be compromised (Kilham 1966). As a result, population densities of both primary and secondary cavity nesters may decline.

In order to maintain the population levels of primary cavity-excavators it is essential to provide adequate habitat through efficient forest management. Snags and snag patches may be most efficient if they are placed within 100 metres of the forest edge, as this limits susceptibility of forest-dwelling birds to predators. The retention of trees for the purpose of managing cavity nesting birds should focus on maintaining a high deciduous component within the stand. Cavity nesters tended to select a high level of deciduous trees for cavity excavation throughout this study. Maintaining a variety of deciduous and coniferous trees within cutblocks could prove to be beneficial for population densities of cavity nesters, as well as many other species of snag users.

\section{Acknowledgments}

We thank Sarah Parsons, Emma Tayless, and Derrick Lalonde for their help in the field, as well as Rod Lenton and Chris Jones from Timberline Forest Inventory Consultants Ltd. for providing maps and access advice. We thank Kelly Sherman for providing advice for sample planning as well as proof-reading numerous drafts. Susan Stevenson and two anonymous reviewers kindly provided feedback on the manuscript

Documents Cited (marked $*$ in text)

Backhouse, F., and J. D. Lousier. 1991. Silviculture systems research: wildlife tree problem analysis. B.C. Ministry of Forests, Ministry of Environment, Wildlife Tree Committee, Victoria, British Columbia.

Davis, L. R., M. J. Waterhouse, and H. M. Armleder. 1999. A comparison of the breeding bird communities in seral stages of the ESSF in east central British Columbia. 
Research Branch, B.C. Ministry of Forests. Victoria, British Columbia. Working paper 39/1999.

Machmer, M. M., and C. Steeger. 1995. The ecological roles of wildlife tree users in forest ecosystems. B.C. Ministry of Forests. Victoria, British Columbia.

Ministry of Forests. 2000. Describing Ecosystems in the Field. Volume 25. http://www.for.gov.bc.ca/hfd/pubs/Docs/ Lmh/Lmh25/06_Taw.pdf

\section{Literature Cited}

Conner, O. K., J. R. Miller, and C. S. Adkisson. 1976. Woodpecker dependence on trees infected by fungal heart rots. Wilson Bulletin 88: 575-581.

Corral, M. 1989. The world of birds: A layman's guide to ornithology. The Globe Pequot Press, Chester, Connecticut.

Desrochers, A., and S. Hannon. 1997. Gap crossing decisions by forest songbirds during the post-fledging period. Conservation Biology 11: 1204-1210

Ehrlich, P. R., D. S. Dobkin, and D. Wheye. 1988. The Birder's Handbook: A Field Guide to the Natural History of North American Birds. Simon and Schuster Inc. New York, New York.

Fort, K. T., and K. A. Otter. 2004. Effects of habitat disturbance on reproduction in Black-capped Chickadees (Poecile atricapillus) in northern B.C. Auk 121: 1070-1080

Gates, J. E., and L. W. Gysel. 1978. Avian nest dispersion and fledging success in field-forest ecotones. Ecology 59: 871-883.

Haapanen, A. 1965. Bird fauna of the Finnish forests in relation to forest succession. Animal Zoology 2: 153-196.

Hegner, R. E. 1985. Dominance and anti-predator behavior in blue tits. Animal Behaviour 33: 762-768.

Kilham, L. 1966. Reproductive behaviors of hairy woodpeckers. I. Pair formation and courtship. Wilson Bulletin 78: 251-265.

Lens, L., and A. A. Dhondt. 1994. Effects of habitat fragmentation on the timing of Crested Tit Parus cristatus natal dispersal. Ibis 136: 147-152

McElveen, J. D. 1979. The edge effect on a forest bird community in North Florida. Proceedings Southeast, Association of Fish and Wildlife Agencies 31: 212-215.

Machtans, C. S., M. A. Villard, and S. J. Hannon. 1996. Use of riparian buffer strips as movement corridors by forest birds. Conservation Biology 10: 1366-1379.

MacKinnon, A., J. Pojar, and R. Coupe. 1992. Plants of Northern British Columbia. BC Ministry of Forests and Lone Pine Publishing. Vancouver, British Columbia.
Mannan, R. W., E. C. Meslow, and H. M. Wight. 1980. Use of snags by birds in Douglas-fir forests, western Oregon. Journal of Wildlife Management 44: 787-797.

Marcot, B. G. 1983. Snag use by birds in Douglas fir clearcuts. In Snag habitat management: proceedings of the symposium. USDA Forest Service General Technical Report RM-99. 19-23.

Martin, K., and J. M. Eadie. 1999. Nest Webs: a community wide approach to the management and conservation of cavity nesting birds. Forest Ecology and Management 115: 243-257.

Peterson, A. W., and T. C. Grubb. 1983. Artificial trees as a cavity substrate for woodpeckers. Journal of Wildlife Management 47: 790-798.

Pojar, R. A. 1995. Breeding bird communities in Aspen forests of the sub-boreal spruce (dk subzone) in the Prince George Forest Region. British Columbia Ministry of Forest Land Management Handbook, Victoria, British Columbia.

Raphael, M. G., and M. W. White. 1984. Use of snags by cavity nesting birds in the Sierra Nevada. Wildlife Monographs (86): 66.

Runde, D. E., and D. E. Capen. 1987. Characteristics of northern hardwood trees used by cavity nesting birds. Journal of Wildlife Management 51: 217-223.

Short, L. L. 1979. Burdens of the picid hole-excavating habit. Wilson Bulletin 91: 16-28.

Smith, D. M., B. C. Larson, M. J. Kelty, and P. M. S. Ashton. 1997. The practice of silviculture: Applied forest ecology. John Wiley and Sons, New York.

Streikle, W. K, and J. G. Dickson. 1980. Effect of forest clearcut edge on breeding birds in east Texas. Journal of Wildlife Management 44: 559-567.

Thomas, J. W., R. B. Anderson, C. Maser, and E. L. Bull. 1979. Snags. Pages 60-70 in Wildlife Habitats in managed forests, Blue Mountains of Oregon and Washington. Edited by J. W. Thomas. U.S. Forest Service Agriculture Handbook 553, Washington, D.C.

Zarnowitz, J. E., and D. A. Manuwal. 1985. The effects of forest management on cavity nesting birds in northern Washington. Journal of Wildlife Management. 49: 255263.

Received 28 March 2003

Accepted 1 October 2004 